\title{
Unmet needs in allergic rhinitis: international survey on management of allergic rhinitis by physician and patient. The physicians' view (ISMAR 2 study)
}

\author{
Carlos E Baena-Cagnani ${ }^{1 *}$, Ashok Mahashur ${ }^{2}$, Jamal Jawad ${ }^{3}$, Margarita Murrieta-Aguttes ${ }^{4}$, Faheem A Tadros ${ }^{5}$, \\ Mohammad Gharagozlou', Talha Mahmud ${ }^{7}$
}

From 3rd WAO International Scientific Conference (WISC) 2014

Rio de Janeiro, Brazil. 6-9 December 2014

\section{Background}

Allergic Rhinitis (AR) is a worldwide spread illness having an important impact on social life, sleep quality, school, and work productivity and huge costs. Patient preference is becoming an important aspect in medical care. ISMAR was designed as the first-over global survey to identify differences in attitudes and preference in patients and physicians about AR. ISMAR 2 is the second phase.

\section{Methods}

ISMAR is an international, multicenter, non-interventional, cross-sectional study in adults and children $(\geq 6$ years) with physician-diagnosed AR of at least 1 year of duration conducted in Algeria, Egypt, United Arab Emirates, Qatar, Kuwait, India, Islamic Republic of Iran, Pakistan, and Saudi Arabia.

Physicians (GPs/Family doctors/internists, pediatricians, allergists/pulmonologists, and ENT) working in public and private sectors or both were selected from master lists of physicians attending AR patients and invited to participate in the study. They answered to the Investigator's Questionnaire (guidelines awareness, relevant AR symptoms, and preference for prescribing medication among others) and recruited consecutive patients to whom the ISMAR questionnaire was administered. Data collection was performed during a single visit. A patient's questionnaire and a Case Record Form were

${ }^{1}$ Research Centre in Respiratory Medicine, Argentina

Full list of author information is available at the end of the article also filled in. Statistical analysis was descriptive. Herein we are showing the physician's view.

\section{Results}

One hundred and seventy eight physicians participated. They were aware about ARIA (82.6\%) and GINA (76.4\%) and followed them to classify patients severity (83.7\%) and for choosing the treatment accordingly (82.0\%). Key symptoms to diagnose AR were congestion (85.4\%), sneezing (93.3\%), and anterior watery rhinorrhea (89.3\%). SQ and AR severity were assessed mainly by clinical history (93.8\% and $98.7 \%)$. The most commonly tests were serum total IgE (52.8\%), eosinophilia (50.0\%), x-rays (48.9\%), CT scan (44.4\%), and allergen skin tests $(39.3 \%)$. The main reasons to prescribe medication were symptom severity/frequency (98.3\%), drug efficacy $(80.3 \% \%)$ and safety $(78.7 \%)$. Other less relevant reasons were personal experience $(60.7 \%)$, route of administration (55.1\%), cost (52.8\%), and frequency of doses (48.9\%). The preferred medications were oral anti$\mathrm{H}_{1}$ antihistamines $\left(\mathrm{Oa}-\mathrm{H}_{1}: 68.5 \%\right)$ and intranasal corticosteroids (ICS: $64.0 \%$ ) [5 in a $0-5$ scale].

\section{Conclusions}

Guidelines are well known and useful to physicians. Clinical history was the main instrument to evaluate patient's SQ, classification and severity of AR, and choice of treatment. Allergen skin tests were not commonly performed. $\mathrm{Oa}-\mathrm{H}_{1}$ and ICS were the most widely recommended treatment for AR and were considered effective and safe. 


\section{Acknowlegements}

The ISMAR study was supported by Sanofi.

\section{Authors' details}

${ }^{1}$ Research Centre in Respiratory Medicine, Argentina. ${ }^{2}$ Hinduja Hospital, India.

${ }^{3}$ Dr Soliman Fakeeh Hospital, Saudi Arabia. ${ }^{4}$ Sanofi, France. ${ }^{5}$ Al Zahra

Hospital, United Arab Emirates. ${ }^{6}$ Children's Medical Center, Iran. ${ }^{7}$ Pakistan.

Published: 8 April 2015

doi:10.1186/1939-4551-8-S1-A232

Cite this article as: Baena-Cagnani et al:: Unmet needs in allergic rhinitis: international survey on management of allergic rhinitis by physician and patient. The physicians' view (ISMAR 2 study). World Allergy Organization Journal 2015 8(Suppl 1):A232.

Submit your next manuscript to BioMed Central and take full advantage of:

- Convenient online submission

- Thorough peer review

- No space constraints or color figure charges

- Immediate publication on acceptance

- Inclusion in PubMed, CAS, Scopus and Google Scholar

- Research which is freely available for redistribution

Submit your manuscript at www.biomedcentral.com/submit 